\title{
ENVIRONMENTAL SUSTAINABILITY OF FAMILY-OWNED AGRICULTURAL HOLDINGS IN THE PODLASKIE VOIVODESHIP
}

\author{
Zofia Kołoszko-Chomentowska', Józefa Wiater², Jan Żukovskis ${ }^{3}$
}

1 Faculty of Management, Bialystok University of Technology, Ojca Tarasiuka 2, 16-001 Kleosin, Poland, e-mail: z.koloszko@pb.edu.pl

2 Faculty of Civil and Environmental Engineering, Bialystok University of Technology, Wiejska 45A, 15-351 Bialystok, Poland, e-mail: j.wiater@pb.edu.pl

3 Faculty of Economics and Management, Aleksandras Stulginskis University, Universiteto 10, LT-53361, Akademija Kaunas, Lithuania, e-mail:jan.zukovskis@asu.It

Received: 2015.07 .17

Accepted: 2015.08.31

Published: 2015.10.01

\begin{abstract}
The subject of this paper is environmental sustainability assessment of agricultural holdings in the Podlaskie voivodeship, participating in the Farm Accountancy Data Network (FADN) in the years 2007-2012. The assessment was conducted based on agro-ecological indicators and environmental burden (material pressure). The analysis was conducted according to a classification into agricultural holding types: field crops, dairy cattle, and mixed holdings. The factor with the strongest impact on the agroecological sustainability of the studied agricultural holdings was the holding type. Field crop and mixed holdings achieved more favorable environmental sustainability indicators. Holdings specializing in dairy cattle breeding pose a threat to the natural environment due to their excessive number of livestock.
\end{abstract}

Keywords: agricultural holdings, sustainability, agro-ecological indicators.

\section{INTRODUCTION}

The search for a model of agricultural development that ensures a high degree of the economic effectiveness of agricultural holdings and implementation of the concept of sustainable development are currently among the most important tasks standing before the agricultural economy. The new EU Common Agricultural Policy for 2014-2020 accounts of environmental sustainability of holdings as an important factor of their further development. Sustainability of agricultural holdings is an element in the concept of sustainable development of rural areas. In this concept, besides satisfying the food needs of the population on an inter-generational scale, ecological, economic, and social objectives with an impact on the sustainability of rural areas are emphasized. Conservation of biodiversity, the resilience and integrity of ecological systems, and land use for development of plant production along with improvement of water use efficiency and soil protection figure among such ecological objectives [Lal 2008]. The objectives concerning areas of economic sustainability include: achievement of income that ensures an equitable living standard for farmers, satisfaction of the population's food needs, and care for the cultural heritage of rural areas [Lawn 2003, Liu 2010]. Among social objectives, ensuring access to socially desirable goods is emphasized [Bartolini et al. 2005].

Agricultural production is strongly linked to environmental order, because it utilizes natural resources to a greater extent than other sectors of the economy, and their status and existing equilibrium are of great significance to the volume and quality of food [Woś 1998]. The technological, biological, and organizational progress that is now taking place provides access to increasingly modern and effective technologies. This leads to the improvement of the technical and economic efficiency of agricultural production, but it also 
causes a series of unfavorable phenomena, such as: deterioration of animal welfare or threats to the natural environment. Therefore, there is a need to integrate measures initiating the search for solutions intended to conserve the features of the natural environment while allowing for the achievement of economic objectives. Socially sustainable agriculture meets these conditions [Krasowicz 2009, Zegar (ed.) 2009, Zegar (ed.) 2013].

In studies of agricultural holdings conducted until now, emphasis was mainly placed on determining the values of production and economic factors, and environmental aspects were marginalized. Now, more and more weight is being attached to environmental aspects, often referred to as agri-environmental, ecological, or agro-ecological aspects. This is a response to the threats posed by human economic activity, which is aggressive towards the natural environment to a greater or lesser extent. Environmental criteria of agricultural sustainable development assessment are also accounted for in legislature [Ustawa ...1994, Ustawa ...2001].

Studies of the sustainable development of agriculture are being conducted at many scientific centers in the country at different levels of management [Sobczyński 2008, Piekut, Machnacki 2011, Wrzaszcz 2011, Harasim 2013a, Zegar (ed.) 2013]. The results of these studies inclined the author to undertake the subject matter of environmental sustainability of agricultural holdings on the regional scale.

The goal of this study was to assess the environmental sustainability of agricultural holdings in the Podlaskie voivodeship. This voivodeship is characterized by specific qualities resulting from the dominance of light soils, in which ecological hazards manifest particularly strongly. Pro-ecological, environment-friendly management methods are preferred [Kuś, Jończyk 2010]. For this reason, the selection of the Podlaskie voivodeship was deemed justified for assessment of the environmental sustainability of agricultural holdings.

\section{MATERIAL AND METHODS}

The research problem was undertaken based on data from agricultural holdings in the Podlaskie voivodeship that participated in the Farm Accountancy Data Network (FADN) in the years 2007-2012. This data is gathered by the Institute of Agricultural and Food Economics in Warsaw.
Variables characterizing holdings are unequivocally defined, and the algorithms for their calculation are generally available. The availability of reliable data was a condition that was accepted during selection of holdings for study.

Selected agro-ecological indicators were applied for environmental sustainability assessment, and they included: share of permanent grassland (meadows and pastures) in the area of farmland $(\%)$, diversity of plants cultivated on arable land (number of species), share of cereals in crops (\%), soil coverage with vegetation throughout the year (\%), number of livestock (LU $\left.\cdot \mathrm{ha}^{-1}\right)$, balance of fertilizer ingredients $\left(\mathrm{kg} \cdot \mathrm{ha}^{-1}\right)$.

Calculations of indicators were carried out according to the methodology proposed by Harasim [2013b]. The assessment was supplemented with indicators characterizing the burden on the environment caused by production factors, which indicate the intensity of management, called "material pressure indicators" by some authors [Piekut, Machnacki 2011]. These are: indirect consumption, value of mineral fertilizers and plant protection products, value of purchased feed, and energy consumption. The index of costs sustained for purchasing mineral fertilizers and plant protection products is of limited value in the assessment of holding sustainability, however, it can be of diagnostic value and serve as a criterion in trend assessment [Sobczyński 2008].

The balance of individual fertilizer ingredients is also important in the aspect of fertilization [Kopiński 2006]. Research took the nitrogen balance into account, which indicates the degree of its use in agrocoenoses and is an important ecological indicator of the degree of plant production sustainability at the level of the agricultural holding.

Naturally, the environmental impact of an agricultural holding depends on its specialization, which is why analysis was conducted according to a classification into the following agricultural types of holdings: field crops (46 holdings), dairy cattle (133 holdings), and mixed holdings (179 holdings), located in all of the poviats of the Podlaskie voivodeship. These were family-owned holdings.

\section{RESULTS AND DISCUSSION}

The holdings subject to study are diverse in terms of the production factors they are equipped with (Table 1 ). They primarily vary in their areas of farmland, which was greater by $68 \%$ in 
field crop holdings than in dairy cattle holdings, and greater by $88 \%$ than in mixed holdings. The structure of farmland corresponds to the selected directions of production: the largest area of permanent grasslands is present in dairy cattle holdings, where grasslands constitute the feed base for livestock. Permanent grasslands perform various ecological functions, and their greater share in the farmland structure may potentially reduce the pressure of animal production on the environment. From this perspective, dairy cattle holdings seem to have better results.

Total employment in holdings was in the range from 1.79 to $1.88 \mathrm{AWU}$, and this was mainly the work of family members; hired labor made up a small share. The greatest employment per 100 ha of farmland was found in mixed holdings and it amounted to $7.3 \mathrm{AWU}$, compared to 6.8 AWU in dairy cattle holdings and 4.0 AWU in field crop holdings. The value of fixed assets indicates the technical level of a holding's equipment. Dairy cattle holdings were the best technically equipped, which is expressed by greater labor and land infrastructure provided by fixed assets.

In the Community Typology for Agricultural Holdings [Decyzja... 1985] the studied holdings are classified as small-medium. Their economic size ranges from 12.56 to $14.17 \mathrm{ESU}$.
The crop structure was characterized by good species diversity of cultivated plants. A minimum of 4 plants were cultivated in all holdings groups, and this is compliant with the principles of good agricultural practice (Table 2). The number of cultivated plants was lower in specialized holdings than in unspecialized holdings. This phenomenon is rather common. Simplification of the crop structure is a common practice in specialized holdings, which leads to monocultural crops and monotony of the landscape in many cases.

The assessment of the organization of plant production based on crop structure only had a favorable result in dairy cattle holdings in the years 2010 and 2012, in which the share of cereals in the crop structure did not exceed $66 \%$. In other holdings, this index was significantly higher, particularly in mixed holdings (from 84.1 to $86.7 \%$ ). In such cases the ecological equilibrium of agrocoenoses is violated.

An important aspect of the ecological sustainability of holdings is keeping the soil surface of arable land under vegetation cover for as long as possible. According to the Code of Good Agricultural Practice, approx. $60 \%$ of the surface of arable land in flatlands, and at least $75 \%$ of the surface of grounds threatened by erosion, should remain under vegetation cover throughout the

Table 1. Basic production factors in the studied holdings (average values from the years 2007-2012)

\begin{tabular}{|l|c|c|c|}
\hline \multirow{2}{*}{\multicolumn{1}{|c|}{ Specification }} & \multicolumn{2}{c|}{ Type of farming } \\
\cline { 2 - 4 } & field crops & dairy cattle & 24.53 \\
\hline Utilised agricultural area (ha) & 46.23 & 27.40 & 33.20 \\
\hline Including: permanent grassland (\%) & 11.10 & 48.75 & 1.79 \\
\hline Total labour input $\left(\mathrm{AWU}^{1}\right)$ & 1.86 & 1.88 & 1.73 \\
\hline Family labour input $\left(\mathrm{FWU}^{2}\right)$ & 1.58 & 1.87 & 168970 \\
\hline Total fixed assets $\left(\mathrm{PLN} \cdot \mathrm{AWU}^{-1}\right)$ & 219317 & 223345 & 12998 \\
\hline Total fixed assets $\left(\mathrm{PLN} \cdot \mathrm{ha}^{-1}\right)$ & 10190 & 17732 & 12.56 \\
\hline Economic size $\left(\mathrm{ESU}^{3}\right)$ & 14.17 & 13.54 & \\
\hline
\end{tabular}

Comments: 1 - Annual Work Unit, 2 - Family Work Unit, 3 - European Size Unit.

Table 2. Indicators for agro-ecological assessment characterizing the holdings studied in the years 2007-2012

\begin{tabular}{|c|c|c|c|c|c|c|c|c|c|}
\hline \multirow{2}{*}{ Specification } & \multicolumn{3}{|c|}{ field crops } & \multicolumn{3}{|c|}{ dairy cattle } & \multicolumn{3}{|c|}{ mixed } \\
\hline & 2007 & 2010 & 2012 & 2007 & 2010 & 2012 & 2007 & 2010 & 2012 \\
\hline Share of cereals in sowing (\%) & 73.0 & 73.4 & 78.2 & 73.5 & 66.1 & 61.5 & 86.0 & 84.1 & 86.7 \\
\hline $\begin{array}{l}\text { Number of species of crops on } \\
\text { arable land }\end{array}$ & 6 & 6 & 5 & 5 & 4 & 4 & 8 & 8 & 7 \\
\hline $\begin{array}{l}\text { Soil coverage with vegetation } \\
(\% \text { arable land })\end{array}$ & 58.0 & 54.1 & 62.0 & 30.3 & 38.4 & 40.2 & 45.7 & 44.7 & 42.2 \\
\hline Nitrogen balance $\left(\mathrm{kg} \mathrm{N} \cdot \mathrm{ha}^{-1}\right)$ & 39.7 & 51.0 & 55.4 & -76.6 & -68.2 & -98.9 & 31.1 & 18.7 & 24.2 \\
\hline $\begin{array}{l}\text { Number of livestock - stocking } \\
\text { density }\left(\mathrm{LU} \cdot \mathrm{ha}^{-1}\right)\end{array}$ & 0.45 & 0.24 & 0.43 & 1.73 & 1.93 & 1.78 & 1.24 & 1.19 & 1.14 \\
\hline
\end{tabular}


whole year [Duer et al. 2002]. The studied holdings are located on flatlands (plains). The index of soil coverage by vegetation throughout the year was unfavorable in all holdings with the exception of field crop holdings in 2012, thanks to the greater share of winter crops in the crop structure.

Fertilization is a basic crop-growing factor, as well as one of the primary indicators for the assessment of management intensity. Despite having a leading role in plant production technology, fertilization can have both positive and negative effects. Irrational fertilization is linked to economic and environmental risk. The balance of mineral ingredients is an important agri-environmental indicator of the correctness of fertilizer ingredient management. A positive gross nitrogen balance within the range of 30-70 kg per 1 ha of farmland is accepted to be safe for the environment [Kopiński 2006]. In the Podlaskie voivodeship, this balance can reach a maximum of 75.9 $\mathrm{kg}$ per 1 ha of farmland [Kopiński 2008]. Holdings specializing in field crops and without specialized holdings met these conditions. In dairy cattle holdings, the nitrogen balance was negative in the period of study, despite the fact that it is well known that holdings producing milk pose a threat to the natural environment, primarily due to high positive balances of fertilization ingredients originating from natural fertilizers. Research conducted by other authors shows that, in the case of a large share of permanent grasslands in the farmland structure, there is a reduction of the intensity of fertilization, which, in consequence, leads to a reduction of the balances of fertilizer ingredients [Harasim, Madej 2008]. Such dependencies, linked to the presence of permanent grasslands ( $48.75 \%$ on average), were observed in the dairy cattle holdings.

Livestock are also linked to environmental restrictions on animal production, which concern, above all, potential threats resulting from agricultural use of animal excrements. The average number of livestock in field crop and mixed holdings did not pose a threat to the natural environment because it did not exceed the acceptable level of $1.5 \mathrm{LU} \cdot \mathrm{ha}{ }^{-1}$ [Duer et al. 2002]. Dairy cattle holdings posed such threats, because the number of livestock significantly exceeded the upper livestock limit that has been accepted in good agricultural practice.

Indirect consumption per 1 ha of farmland is a general indicator of burden (material pressure) on the environment [Piekut, Machnacki 2011]. It encompasses direct costs and general holding costs related to the operations of the agricultural holding. Dairy cattle holdings were characterized by a greater value of indirect consumption, which was due mainly to the high costs of purchasing feed. The average indirect consumption value in this group amounted to PLN 3287 per 1 ha of farmland in the years 2007-2012 and was greater by $16 \%$ than in mixed holdings and greater by $46 \%$ than in field crop holdings.

Agricultural holdings specializing in field crops were distinguished by a greater consumption of mineral fertilizers and plant protection products than other groups, which should be acknowledged as justified in this case, however, they exerted greater pressure on the environment as a result. Dairy cattle holdings where characterized by the greatest consumption of purchased production factors, and the value of this indicator amounted to PLN $2301 \cdot \mathrm{ha}^{-1}$. This value was slightly (7\%) lower for mixed holdings.

Changes in the intensity of production over time indicate that a growing burden caused by production factors in all holding groups is being placed on the environment (Table 3 ). In a synthetic agro-ecological assessment [Harasim 2013b], field crops and mixed holdings exhibited an av-

Table 3. Changes of production intensity in holdings studied in the years 2007-2012

\begin{tabular}{|c|c|c|c|c|c|c|c|c|c|}
\hline \multirow{2}{*}{ Specification } & \multicolumn{3}{|c|}{ field crops } & \multicolumn{3}{|c|}{ dairy cattle } & \multicolumn{3}{|c|}{ mixed } \\
\hline & 2007 & 2010 & 2012 & 2007 & 2010 & 2012 & 2007 & 2010 & 2012 \\
\hline $\begin{array}{l}\text { Total intermediate } \\
\text { consumption }\left(\mathrm{PLN} \cdot \mathrm{ha}^{-1}\right)\end{array}$ & 2320 & 1479 & 2962 & 2485 & 3122 & 4254 & 2598 & 2317 & 3587 \\
\hline $\begin{array}{l}\text { Mineral fertilizers } \\
\left(\mathrm{PLN} \cdot \mathrm{ha}^{-1}\right)\end{array}$ & 397.69 & 404.02 & 630.46 & 264.20 & 359.43 & 506.35 & 262.98 & 287.57 & 385.28 \\
\hline $\begin{array}{l}\text { Plant protection products } \\
\left(\mathrm{PLN} \cdot \mathrm{ha}^{-1}\right)\end{array}$ & 173.34 & 180.96 & 187.27 & 39.58 & 53.54 & 62.30 & 54.27 & 58.39 & 70.24 \\
\hline $\begin{array}{l}\text { Value of purchased feed } \\
\left(\mathrm{PLN} \cdot \mathrm{ha}^{-1}\right)\end{array}$ & 750.46 & 740.96 & 812.98 & 1065.66 & 1276.44 & 1888.86 & 1358.87 & 937.41 & 1851.23 \\
\hline $\begin{array}{l}\text { Energy consumption } \\
\left(\mathrm{PLN} \cdot \mathrm{ha}^{-1}\right)\end{array}$ & 321.48 & 336.89 & 578.37 & 320.14 & 437.88 & 628.92 & 283.25 & 351.70 & 467.49 \\
\hline
\end{tabular}


erage level of environmental sustainability, and dairy cattle breeding holdings had a low level of environmental sustainability.

\section{CONCLUSIONS}

The concept of sustainable agriculture is intended to link economic development to protection of natural resources and the equilibrium of ecosystems. The following measures have been placed in the foreground of this movement: creation of conditions for permanent and sustainable development of rural areas, and promotion of environment-friendly agriculture. A special task has been assigned to agricultural holdings, towards which there are great expectations, with regard to the quantity of produced food, to the quality of this food, and to protection of natural resources. Thus, there is a need to conduct studies on the sustainability of agricultural holdings.

The factor with the strongest impact on the agro-ecological sustainability of the studied agricultural holdings was the direction of production defined by the agricultural type of the holding. All holdings were characterized by good species diversity of cultivated plants, however, they achieved unfavorable results in terms of soil coverage by vegetation. With respect to mineral fertilization, a correct nitrogen balance was only registered in mixed holdings. Holdings specializing in livestock production exhibited a greater degree of environmental sustainability in the scope of such indicators as: share of permanent grasslands and crop structure. However, this direction of production poses great threats to the environment due to the excessive number of livestock.

The environmental burden (material pressure) indicator, expressed by the value of indirect consumption per 1 ha of farmland, was also the greatest for dairy cattle holdings. Holdings specializing in field crops and mixed holdings achieved more favorable indicators in point assessment of environmental sustainability. Thus, the owners of holdings specializing in breeding dairy cattle stand before the challenge of reconciling economic objectives with respect for the principles of environmental protection, particularly since subsidization of agricultural holdings with EU funds is contingent upon the achievement of environmental objectives in agricultural activity.

\section{Acknowledgements}

The article is a part of a Polish-Lithuanian research project within the framework of scientific cooperation between the Polish Academy of Sciences and the Lithuanian Academy of Sciences.

\section{REFERENCES}

1. Bartolini F., Gallerani V., Raggi M., Wiaggi D., 2005. Contract Design and Targeting for the Production of Public Goods in Agriculture: The impact of the 2003 CAP Reform. International Congress European Association of Agricultural Economists. August 24-27, Copenhagen, Denmark, 1-12.

2. Decyzja Komisji (EWG) z 7 czerwca 1985 r. ustanawiająca wspólnotową typologię gospodarstw rolnych (85/377/EWG).

3. Duer I., Fotyma M., Madej A., 2002. Kodeks dobrej praktyki rolniczej. MRiRW-MŚ-FAPA, Warszawa, pp. 96.

4. Harasim A., 2013a. Agroekologiczna ocena zrównoważenia uspołecznionych gospodarstw rolnych. Rocz. Nauk. Stow. Ekon. Roln. i Agrobiz., 15(2), 101-105.

5. Harasim A., 2013b. Metoda oceny zrównoważonego rozwoju rolnictwa na poziomie gospodarstwa rolnego. Studia i Raporty IUNG-PIB, Puławy, 32(6), 25-75.

6. Harasim A., Madej A., 2008. Ocena poziomu zrównoważonego rozwoju gospodarstw bydlęcych o różnym udziale trwałych użytków zielonych. Rocz. Nauk Roln., seria G 95(2), 28-38.

7. Kopiński J., 2006. Bilans składników nawozowych w gospodarstwach rolnych jako kryterium zrównoważonego gospodarowania, (In:) J.S. Zegar (Ed.) $\mathrm{Z}$ badań nad rolnictwem społecznie zrównoważonym. IERiGŻ-PIB, Warszawa, 30, 83-91.

8. Kopiński J., 2008. Określenie kryteriów do obliczenia sald głównych składników nawozowych w ujęciu województw. IUNG-PIB, Puławy (materiały niepublikowane).

9. Krasowicz S., 2009. W Polsce powinno dominować rolnictwo zrównoważone. (In:) A. Harasim (Ed.) I Kongres Nauk Rolniczych „Przyszłość sektora rolno-spożywczego i obszarów wiejskich". IUNG-PIB Puławy, 21-38.

10. Kuś J., Jończyk J., 2010. Produkcyjna i środowiskowa ocena różnych systemów gospodarowania. Zesz. Probl. Post. Nauk Roln., 547, 193-204.

11. Lal R., 2008. Soils and sustainable agriculture. A review. Agron. Sustain. Dev., 28 (1), 57-64.

12. Lawn P.A., 2003. A theoretical foundation to support the Index of Sustainable Economic Welfare 
(ISEW), Genuine Progress Indicator (GPI) and other related indexes. Ecol. Econ., 44, 105-118.

13. Liu Y., 2010. Establishing Modern Concept of Wealth. Promoting Chinese Social Sustainable Development. J. Sustain. Dev. 3(4), 248-251.

14. Piekut K., Machnacki M., 2011. Ocena ekologiczno-ekonomiczna gospodarstw rolnych na podstawie danych FADN. Woda-Środowisko-Obszary Wiejskie, 11(1), 203-219.

15. Sobczyński T., 2008. Zmiany poziomu zrównoważenia gospodarstw rolnych UE w latach 19892005. Rocz. Nauk Roln., Seria G, 94(2), 106-114.

16. Ustawa o ochronie i kształtowaniu środowiska (Dz. U. 1994, nr 49, poz. 196 z póź. zm.).
17. Ustawa Prawo ochrony środowiska (Dz. U. 2001, nr 60, poz. 267 z póź. zm.).

18. Woś A., 1998. Rozwój zrównoważony. Encyklopedia Agrobiznesu, red. A. Woś. Fundacja Innowacji, Warszawa, pp. 741.

19. Wrzaszcz W., 2011. Poziom zrównoważenia środowiskowego indywidualnych gospodarstw rolnych w Polsce (na podstawie danych FADN). Rocz. Nauk. Stow. Ekon. Roln. i Agrobiz., 13(5), 70-75.

20.Zegar J.S. (Ed.), 2009. Z badań nad rolnictwem społecznie zrównoważonym. Program Wieloletni. IERiGŻ-PIB Warszawa, 161, 1-156.

21. Zegar J.S. (Ed.) 2013. Zrównoważenie polskiego rolnictwa. GUS Warszawa. 